\title{
Occurrence of toxigenic cyanobacterial blooms in freshwaters in Sri Lanka.
}

\author{
JAYATISSA, L.P., SILVA, E.I.L., MCELHINEY, J. and LAWTON, L.A.
}




\section{Risk of toxigenic cyanobacterial blooms in freshwaters of Sri Lanka}

Jayatissa, L. P. ${ }^{1}$, Silva, E. I. L. ${ }^{2}$, McElhiney, $\mathrm{J}^{3}$, and Lawton, L. A. ${ }^{3 *}$

${ }^{1}$ Department of Botany, University of Ruhuna, Matara, Sri Lanka.

${ }^{2}$ Institute of Fundamental studies, Hantana Road, Kandy, Sri Lanka.

${ }^{3}$ School of Life Sciences, Robert Gordon University, St. Andrew Street, Aberdeen AB25 1HG, Scotland.

*Corresponding author: email: 1.lawton@rgu.ac.uk

Running Title: Toxic cyanobacterial blooms in Sri Lanka 


\section{SUMMARY}

A previous pioneering study of freshwater bodies in Sri Lanka revealed the presence of toxic cyanobacteria in three out of four water bodies tested. It was therefore important to perform a more detailed investigation into the presence of cyanobacteria and their toxins throughout Sri Lanka. The country has a long history of well-planned water management with the agricultural economy and drinking water supply still dependent on thousands of man-made tanks. Seventeen reservoirs from different user categories and different climatic zones were selected to study variations in phytoplankton communities with relation to major nutrients, with particular emphasis on cyanobacteria. The study was carried out during a two-year period and heavy growths or blooms of cyanobacteria observed during the study period were tested for microcystins. The results clearly categorised the 17 reservoirs into four groups parallel to the classification based on the user categories of water bodies. Biomass of total phytoplankton, the abundance of cyanobacteria, the dominance of Microcystis spp. and concentration of nitrate $(\mathrm{N})$ and total phosphorous $\{\mathrm{P})$ were the lowest in drinking water bodies and the highest in aesthetic water bodies. Irrigation water bodies showed the second lowest values for phytoplankton biomass, and concentration of $\mathrm{N}$ and $\mathrm{P}$, while hydropower reservoirs showed the second highest values for the same parameters. The fraction of cyanobacteria in irrigation waters was higher than that in hydropower reservoirs, but surprisingly the dominance of Microcyslis spp. was reversed. Possible reasons for these variations are discussed. More than half of the bloom material tested contained microcystins up to $81 \mu \mathrm{g} 1^{-1}$. Our findings indicate the potential for high-risk situations due to toxigenic cyanobacterial blooms in susceptible freshwaters of Sri Lanka.

Keywords: Phytoplankton, cyanobacteria, microcystins, cyanotoxins, eutrophication. 


\section{Introduction}

Cyanobacteria are a group of prokaryotes that occur in fresh, brackish and marine waters all over the world, but most commonly in temperate and tropical freshwaters. One feature of cyanobacteria is their frequent formation of mass growths known as blooms in water bodies creating aesthetic, operational and health problems [8, 19,21]. Concern regarding the potential health problems created by cyanobacterial blooms has increased dramatically in the recent past as a number of genera have become widely recognised as toxin producers $[5,22]$. According to the literature, over one hundred species of cyanobacteria belonging to forty genera are reported to be toxigenic. However, Anabaena, Aphanizomenon, Cylindrospermopsis, Lyngbya, Microcystis, Nostoc, Nodularia and Oscillatoria (Planktothrix) are recognised as the most important genera having toxigenic species $[7,8]$.

Cyanotoxins (i.e. the toxins produced by cyanobacteria) include the neurotoxins; anatoxin-a, anatoxin-a(s) and the saxitoxins plus the hepatotoxins; microcystins, nodularins and cylindrospermopsins. In addition cyanobacteria produce other secondary metabolites that may be of potential pharmacological use $[7,18]$. Cyanotoxins are responsible for intoxication and deaths of livestock, wildlife and pets world-wide. Reports also exist of the deaths of humans as a result of exposure to cyanotoxins. The most widely reported example occurred in 1996, when the deaths of sixty patients undergoing dialysis treatment in Caruaru, Brazil were attributed to cyanotoxins which had contaminated the clinic's water supply [26]. However, acute lethal injury to humans from consuming cyanobacteria in drinking water is still regarded as unlikely. This is because cyanotoxins are usually contained within cells, which should be removed during water purification. However, cyanotoxins can be released and dissolved in the surrounding water during the natural decomposition of cells or following certain water treatment methods. Furthermore, evidence has suggested that part per billion levels of microcystins and nodularins may be associated with chronic health effects including tumour promotion $[6,27]$. Some cyanotoxins have also been detected in aquatic animals which feed on toxic cyanobacteria indicating that cyanotoxins may bio-accumulate at higher trophic levels and pose a health threat for consumers $[6,15]$. More recently, studies have revealed that cyanotoxins can be taken up by higher plants and affect their growth [24]. This indicates that the presence of toxic cyanobacteria in irrigation water may have considerable impact on the growth and development of crop plants [23, 25]. These 
findings suggest that the impact of cyanotoxins is not restricted to those organisms affected by acute toxic exposure.

Since ancient times, the ecology and economy of Sri Lanka, a tropical continental island located between latitude $5055^{\text {' }} \mathrm{N}$ and 9050 ' $\mathrm{N}$ and longitude 790 $42^{\prime} \mathrm{E}$ and 810 52' $\mathrm{E}$, have been greatly influenced by its intense network of freshwaters. It comprises one hundred and three rivers, and more importantly, about ten thousand man-made tanks. Concern about cyanobacterial blooms in freshwaters of Sri Lanka has also grown in recent years due to a variety of reasons. These include; frequent recordings of cyanobacterial blooms, problems created by blooms formed in aesthetic water bodies in the capital and some other cities, records on toxic blooms and suspected fish kills by cyanobacterial blooms [2, 19, 20, 33, 34, 37]. In addition to this, a patchy distribution of thick cyanobacterial scum in irrigation water bodies in Sri Lanka is commonly observed, particularly in the dry season [35, 37]. However, studies on the distribution and bloom formation of cyanobacteria in freshwaters of Sri Lanka are scarce. Furthermore, toxigenic cyanobacteria have not been examined despite the fact that waters in most of the irrigation reservoirs, particularly in the dry zone of Sri Lanka, are also used for drinking, without appropriate purification [3]. In a previous study, Jayatissa et al. [19] reported the presence of toxins in two Sri Lankan cyanobacterial bloom samples. This pioneering work on toxic cyanobacteria in fresh waters of Sri Lanka triggered a more detailed study using a larger sample size in order to provide a more accurate indication of the occurrence of cyanobacteria and their toxins.

The aim of the present study was two-fold. Firstly to quantify the contribution of cyanobacteria to the phytoplankton community in a set of freshwaters selected from different user categories. Secondly, to test cyanobacterial blooms and samples from the water column for their toxin content.

\section{Materials and Methods}

There are no natural lakes in Sri Lanka but thousands of man-made, perennial tanks. Although many of these are multipurpose, they can be divided into four user categories according to their major use; irrigation tanks, hydropower reservoirs, drinking water reservoirs and aesthetic water bodies. The present study was carried out on seventeen water bodies representing the above four categories and located in three major climatic zones (i.e. lowland wet zone, upland wet zone and dry zone) of Sri Lanka (Table 1). Sampling commenced in June 1998 and continued until May 
2000. Sub-surface water samples were collected monthly from the centre of each water body and if surface scum were observed, those were collected separately.

The $\mathrm{pH}$ of water was measured in situ using a portable $\mathrm{pH}$ meter (Genway $3030 \mathrm{pH}$ meter). Samples of scum material for phytoplankton analysis were preserved with $5 \%$ formalin. Water samples $(500 \mathrm{ml})$ for phytoplankton analysis were preserved in Lugol's iodine solution (100:1 ratio by volume) and kept in darkness to preserve phytoplankton for enumeration in the laboratory. Water samples were brought to the laboratory on the same day of collection. Total phosphorous and total nitrogen in water were analysed according to standard methods [4].

Preserved samples of water or surface scum were observed under the microscope for species composition using a Neubauer haemocytometer. Taxonomic description given in Abeywickrama [1], Cox, [12], Descikachary [14], Rott [28] and Rott and Lezenweger [29] were used for identification of phytoplankton. Density (i.e. number of cells), frequency (i.e. number of individual colonies, filaments or cells) and bio-volume (i.e. volume of cells) of each species were enumerated. To calculate the cell volume colonies, single cells or parts of cells were allocated to a geometrical entity i.e. cone, sphere or cylinder, based on the shape. The objective of this enumeration was to assess the abundance or dominance of total cyanobacteria as well as quantify the presence of some of the known toxigenic species, compared to the other phytoplankton species present in the same water body. However, none of these three attributes alone is a reliable parameter to assess the dominance of a particular species as each parameter suffers some limitations. For example, the frequency will give little information on the quantity as filaments or colonies can greatly differ in size or number of cells present, even in the same species. The density alone also is not a good parameter to compare the dominance as the cell sizes of different species could be different. In terms of density, cyanobacteria could 'dominate' a water body, but their bio-volume could be smaller than the other apparently non-dominant phytoplankton taxa, because cell sizes of most of the cyanobacterial species are smaller than for example diatoms or green algae. To overcome these problems 'Important Value Index' (IVI) was adopted, a method developed by Curtis and McIntosh [13] to assess the dominance of forest species by combining the standardised density, frequency and basal area. This method was applied to water samples to produce a comparable IVI for each phytoplankton taxa by replacing 'basal area' of forest species with 'bio-volume' of phytoplankton species. By standardising each of the three attributes of a given species with respect to the sum total of that 
attribute of all the species of the sample, the relative value can be obtained. For example, the relative density of a species is its density expressed as a percentage of the total density of all the species. The relative frequency and relative cell volume are calculated in a similar manner. This attribute was more reliable to assess the dominance of different phytoplankton taxa in the same water body.

Samples for microcystin analysis were only collected at sites where known toxigenic species were observed at relatively high cell numbers. For microcystin analysis, a known volume of water (depending on the density of phytoplankton) was filtered through $110 \mathrm{~mm} \mathrm{GF/C} \mathrm{disks} \mathrm{(Whatman).} \mathrm{Filter} \mathrm{papers} \mathrm{which} \mathrm{had} \mathrm{retained}$ cyanobacterial cells were folded with the upper surface innermost, placed in a glass vial and freeze dried prior to extraction. Samples of surface scum were also concentrated by filtering and freeze-dried.

Individual colonies of Microcystis aeruginosa were isolated from Kandy Lake scum material using a microscope with a micropipette and cultured for two to three months in BG 11 medium under continuous light. Two isolates were successfully obtained and analysed for microcystin by filtering $50 \mathrm{ml}$ of each culture followed by freeze drying.

All samples were extracted according to the method described by Jayatissa et al. [19] which involved extraction of $100 \%$ methanol followed by rotary evaporation $\left(40^{\circ} \mathrm{C}\right.$ in vacuo) to concentrate the sample. Extracts were analysed using HPLC analysis with photodiode-array (PDA) detection as described by Lawton, Edwards, and Codd [22]. All reagents used were of analytical or HPLC grade. Ten samples of phytoplankton were analysed including samples of surface scum material and filtered water samples shown to contain a high abundance of Microcystis species by microscopy. Microcystins were identified using a spectral library and spectral matching software (Millennium ${ }^{32}$ from Waters). Peaks found to have a close spectral match (i.e. match angle less than 5) were quantified using a microcystin-LR standard. All values for microcystins are reported as microcystin-LR equivalence since it is not possible to use standards for each microcystin. This is due to the general lack of available standards and number of microcystin variants that may occur.

\section{Results}

The mean biovolume of total phytoplankton and the percentage contribution by cyanobacteria in each reservoir are given in Table 2 . The highest biovolume of phytoplankton $\left(>200 \mathrm{~mm}^{3} \mathrm{l}^{-}\right.$ ${ }^{1}$ ), as well as the highest percentage (i.e. $96 \%$ ) of cyanobacteria was recorded from Colombo 
Lake, which has a perennial bloom of two cyanobacterial species (Spirulina sp. and M. aeruginosa). The Spirulina sp was dominant in the water column throughout the lake. Although the abundance of $M$. aeruginosa in the water column was comparatively low, it had formed into a thick surface scum that accumulated at edges of the lake. The second highest biovolume of phytoplankton (i.e. $>150 \mathrm{~mm}^{3} \mathrm{l}^{-1}$ ) were recorded from two tanks, Situlpawwa and Tissawewa, the former of which had experienced a cyanobacterial bloom in 1996 [19]. Chandrikawewa, Kandy Lake, followed by the three hydropower reservoirs (Kotmale, Randenigala and Victoria) $\left(>100<150 \mathrm{~mm}^{3} \mathrm{l}^{-1}\right)$ whilst the biovolume of phytoplankton in the remaining water bodies was comparatively low $\left(<125 \mathrm{~mm}^{3} \mathrm{l}^{-1}\right)$. With the exception of Colombo Lake, the percentage contribution of cyanobacteria to the total phytoplankton biovolume in water bodies ranged from 1.13 to $14.8 \%$. The lowest concentrations of cyanobacteria were recorded in the two drinking water reservoirs, (Kalatuwawa and Labugama), while the highest concentrations occurred in two aesthetic water bodies (Situlpawwa and Kandy Lake).

Table 3 shows the common species of phytoplankton recorded in each reservoir ranked according to their IVIs. Cyanobacteria, diatoms and green algae were the dominant groups of phytoplankton in the water bodies studied. Dianophyceae was also represented by three species, but their IVIs were very low. Diatoms appeared to be a predominant group of phytoplankton in these water bodies due mainly to the higher abundance of a single species (centric diatom), Aulacoseira granulata, in most of the water bodies. Otherwise, the diversity, as well as the abundance of the remaining diatom species recorded in this study was lower compared to that of green algae and cyanobacteria. Taxonomic groups of cyanobacteria and green algae were represented by an even higher number of species, although some of these were recorded only rarely and in low numbers. Identification of such species was also difficult simply due to the poor availability of specimens as well as relevant literature. Therefore, the rare species of which the IVI was less than five, are not included in this list. With the exception of Straurastrum and Pediastrum, the IVI of most of the green algal species was low. At least one Microcystis sp. was recorded from each sample observed from all the reservoirs, indicating that Microcystis are the most common cyanobacterial genus in the studied reservoirs. As can be seen from Table 3, the IVI of Microcystis species almost half of the reservoirs were higher than 25, indicating that the abundance of Microcystis sp. in these water bodies was high. Anabaena sp., Chroococcus sp., and Planktothrix (formerly Oscillatoria) sp. demonstrated the second highest dominance in these reservoirs.

The concentrations of nitrate-nitrogen and total phosphorus, the two most important nutrients affecting bloom formation of cyanobacteria, are given in Table 2. With the exception 
of Tissawewa, all the irrigation tanks sampled had very low concentrations of nitrates and phosphorus. Hydropower reservoirs (i.e. Kotmale, Randenigala, Rantambe and Victoria) and aesthetic water bodies (Colombo, Kandy and Situlpawwa) had higher concentrations of both nutrients.

Microcystins were identified in five of the ten samples of phytoplankton which were analysed for toxins by HPLC. Samples from Situlpawwa and Colombo Lake contained a higher content of microcystin whilst those from Kandy Lake contained relatively less microcystin (Table 1, Table 4). All the microcystin-containing samples were from water bodies that were observed to give high IVI values for $\mathrm{M}$. aeruginosa (table 3) although Tissawewa was the only other water body with a IVI of $>40$ for M. aeruginosa but was found to have no detectable microcystins. Two laboratory isolates of $M$. aeruginosa were obtained from Kandy Lake. The first was found to contain $0.015 \mathrm{mg} \mathrm{g}^{-1}$ microcystin while the second contain no detectable amounts of microcystin.

\section{Discussion}

The reservoirs studied showed distinct variations in the mean total biovolume of phytoplankton, abundance of cyanobacteria and dominance of important toxigenic species as well as total nitrogen and total phosphate concentrations in water. The total biomass of phytoplankton and the abundance of cyanobacteria were lowest in the two reservoirs used exclusively for drinking water. This may be attributed to short residence time resulting from continuous throughput, and lower nutrient load. Labugama and Kalatuwawa are also located in the lowland wet zone, which generally experiences higher rainfall, and a larger percentage of wet zone forests cover the catchment of each of these reservoirs compared with the other water bodies tested. The low concentrations of toxigenic cyanobacteria, coupled with IVI values for $M$. aeruginosa of less than 5, indicates that the abundance and species composition of phytoplankton in these two water bodies would not be expected to constitute a health risk.

With the exception of Tissawewa, the lowland irrigation tanks showed a lower biomass of phytoplankton compared to hydropower reservoirs; but the propostion of cyanobacteria was higher. This may be linked to the fact that all of these irrigation water bodies show a trophic shift from mesotrophic at high water levels (JanuaryApril) to eutrophic towards low water level (August - October) [30], and tend to be shallow and highly turbid. It has been reported that cyanobacteria have a competitive advantage in such conditions as they can maintain a higher growth rate compared to 
the other phytoplankton groups when the light intensities are low [8]. Eighteen out of the forty genera known to include toxigenic species have been identified in Sri Lankan waters $[1,28,29]$, and eleven of these toxigenic species were recorded in this study. However, the dominance of Microcystis, usually the most commonly encountered toxigenic genus, is lower in these irrigation tanks compared to hydropower and aesthetic water bodies. It is possible that the lower concentration of total nitrogen in the water may have favoured the growth of nitrogen fixing cyanobacteria over non-nitrogen fixing cyanobacteria. In lowland irrigation reservoirs in Sri Lanka phosphorous is known to be limited [36], and this phosphorus limitation may account for the lower abundance of Microcystis species [39].

Tissawewa showed a higher biomass of phytoplankton and a larger proportion of cyanobacteria and dominance of Microcystis and Anabaena species than any of the other shallow irrigation tanks. Nitrogen and phosphorus levels were also higher in the water of this man-made tank. The increased levels of nutrients in this water body may be due to an increased level of human impact and wastes from cattle grazing on the surrounding catchment. Tissawewa is located on the way to Kataragama and in the vicinity of Tissamaharama Township. These cities have both historic and religious significance with hundreds of pilgrims passing through each day to worship at the highly respected temples located there. It is customary for pilgrims to stop at this water body to bathe and eat prior to visiting the temples. This may contribute to a higher load of nitrogen and phosphorus, and consequently increased phytoplankton biomass.

Levels of total $\mathrm{N}$ and total $\mathrm{P}$ in the water are higher in three out of the four hydropower reservoirs studied (Kotmale, Randenigala and Victoria) which may account for the higher total biomass of phytoplankton. The higher nutrient concentrations in these deeper highland reservoirs may be a result of intensive agriculture practices and dense human settlement without proper sanitary facilities in their respective watersheds [3]. High concentrations of nitrogen species may promote non-nitrogen fixing cyanobacteria when phosphorus is not limited. Although the fraction of cyanobacteria is lower in these reservoirs compared to that of the irrigation tanks, dominance by Microcystis sp. is apparent. Higher light intensities in the water with deeper euphotic zones may give a competitive advantage for green algae and some diatoms over cyanobacteria whilst higher $\mathrm{N}$ and $\mathrm{P}$ ratio may have favoured the growth of Microcystis species over other cyanobacteria, particularly nitrogen fixing species [39]. Although Rantambe is also a hydropower reservoir with a moderate 
depth $(30 \mathrm{~m})$, it has been drastically reduced during the recent past by heavy siltation [16]. Furthermore, Rantambe has the highest catchment area per unit reservoir area which is used as an index of allochthonous input [34]. This may explain why this water body is more similar to shallow irrigation waters in terms of phytoplankton composition and abundance, than to the other hydropower reservoirs.

The three aesthetic water bodies, Colombo Lake, Kandy Lake and Situlpawwa demonstrated the highest values for phytoplankton biomass, its fraction of cyanobacteria, dominance of Microcystis species and nutrient ( $\mathrm{N}$ and $\mathrm{P}$ ) levels, indicating their significance as the principle examples of hyper-eutrophicated water bodies in Sri Lanka. Colombo Lake has experienced a heavy perennial bloom since the 1960s [11] and has become a nuisance water body with no aesthetic value. Heavy cyanobacterial blooms occurred also in Kandy Lake and Situlpawwa lake during the first part of the study period but decreased later due to flushing and dilution of water by rains. However, the cell density of surface water in both water bodies remained higher than $10^{6} 1^{-1}$ throughout the study period, indicating that bloom levels of cyanobacteria were present, even though there was no scum formation. As Colombo Lake and Kandy Lake are located in the two largest cities of the country, the inputs of industrial, urban and domestic effluents are the obvious reasons for their hypereutrophication. Situlpawwa Lake, is the smallest of water bodies studied located in the grounds of a historic temple with the whole catchment covered by a dry zone forest and only about five permanent residents. However, a religious ceremony takes place there during one week each year, attracting thousands of people. It is therefore likely that the hyper-eutrophication in Situlpawwa Lake is due to faecal pollution.

Half of the cyanobacterial samples tested in this study contained microcystins, indicating the percentage of samples positive for microcystins is comparable to those recorded from European waters [10]. However, in this study, samples were analysed for microcystins only, and not for other cyanotoxins. Concerns regarding cyanobacterial blooms or cyanotoxins in fresh waters of Sri Lanka have only recently begun. Hence, due to the scarcity of required facilities and skilled personnel, many toxic blooms, particularly in rural areas, may go unreported. Previous reports on blooms have revealed the occurrence of toxigenic cyanobacteria [19, 31, 36, 37]. A heavy bloom of M. aeruginosa occurred in Kotmale reservoir in 1991 and although it was not tested for cyanotoxins, inhabitants revealed that some of their cows which normally drink water from the reservoir died unexpectedly during the period of that bloom. The results of this study, coupled with other reported incidents, imply that the 
probability of the cyanobacterial blooms in fresh waters of Sri Lanka being toxic is considerable and warrants regular montoring. It is well established that warmer temperature, lengthy period of sunlight, still and calm water, and eutrophication, particularly with higher abundance of nitrogen and phosphorus, favour the growth of cyanobacteria over the other phytoplankton groups $[5,8-11]$. With the exception of nutrient levels, these factors remain at optimum levels throughout the year in the fresh waters of Sri Lanka [30]. Furthermore, a study carried out by Silva [37] and the results of this study indicate that a considerable number of fresh water bodies in Sri Lanka possess elevated levels of nitrogen and phosphorus. In an analysis based in 17 lakes located world-wide, Smith [38] concluded that bloom-forming cyanobacteria tended to dominate in lakes where the TN:TP mass ration was less than 29. As cited in Chorus and Bartram, [8], the ratio given by Schreurs [32] is in molecules and reports that a range of 10-16 molecules of $\mathrm{N}$ : 1 molecule of $\mathrm{P}$ will favour the growth of cyanobacteria. The two ratios are not comparable, however, as observed in many studies the mass ratio of N:P in fresh waters of Sri Lanka is always less than fifteen $[17,30]$ indicating that the ratio of $\mathrm{N}: \mathrm{P}$ is not likely to hinder the growth of cyanobacteria.

The findings of this investigation indicate that cyanobacteria can readily dominate phytoplankton populations in Sri Lankan waters where the nutrient conditions often favour their growth. Furthermore, since half the blooms tested were found to contain microcystins suitable precautions should be taken when utilising affected water bodies. Further research is now required to predict the impact of toxin containing water and to determine if other cyanotoxins are also present in Sri Lankan water bodies.

\section{Acknowledgements}

This study was financed by a grant (RG/98/B/4) from the National Science Foundation (NSF), Sri Lanka. We thank the 'Mahaweli authority of Sri Lanka' and 'National water supply and drainage board of Sri Lanka' for their permission to collect water samples from relevant water bodies. 


\section{References}

1. Abeywickrama, B. A.: The genera of the fresh water algae of Sri Lanka, pp 103 Part 1 - UNESCO Man and the biosphere national committee for Sri Lanka. Special Publication 6. National Science Council Sri Lanka, Colombo. 1979.

2. Anon: Fish kills in Parakrama Samudra. Sri Lanka Association for Fisheries and Aquatic Resources, News Letter. 1, 1 (1998).

3. Anon: Dam Safety and Reservoir Conservation Programme (Status Report): Activity 13 : Catchment Land Use, Peripheral, Reservoir and Riverine Impacts, Mahaweli Authority of Sri Lanka. p 62 (2003).

4. APHA: Standard methods, water and waste water. $19^{\text {th }}$ edition. American Public Health Association (1989).

5. Carmichael, W. W.: The toxins of cyanobacteria. Sci. Am., 270, 64-72 (1994).

6. Carmichael, W. W.: Cyanobacterial blooms and health hazards - an overview. Toxicon, 34, 299 (1996).

7. Carmichael, W. W.: Health effects of toxin-producing cyanobacteria: "The CyanoHABs" Human Ecol. Risk Assess, 7, 1393-1407 (2001).

8. Chorus, I., Bartram, J. Toxic cyanobacteria in water, A guide to their public health consequences, monitoring and management. WHO, E \& FN Spon, London 1999.

9. Codd, G. A.: Mechanisms of action and health effects associated with cyanobacterial toxins, Toxicology Letters, 88, 21 (1996).

10. Codd, G. A.: Cyanobacterial toxins, the perception of water quality and the prioritisation of eutrophication control. Ecological Engineering, 16, 51-60 (2000). 
11. Costa, H. H., De Silva, S. S.: Hydrology of Colombo (Beira) Lake. Dirnal variations in temperature, hydrochemical factors and zooplankton. Bulletin Fish. Res. Stn Ceylon, 20, 141-149 (1969).

12. Cox, E. J.: Identification of Fresh water diatoms from live material. Chapman and Hall, London 1996.

13. Curtis J. T., McIntosh, R. P.: The interrelationship of certain analytic and synthetic phytosociological characters, Ecology, 31, 434-455 (1950).

14. Descikachary T.V.: Cyanophyta, I.C.A.R. Monographs on Algae New Delhi p 686 (1959).

15. Engstrome-Ost, J., Lehtiniemi, M., Green, S., Kozlowsky-Suzuki, B. Viitasalo, M.: Does cyanobacterial toxin accumulate in mysid shrimps and fish via copepodes? Journal of Experimental Marine Biology and Ecology 276, 95107 (2002).

16. Finlayson, W.: Effects of deforestation and tree planting on the hydrology of the Upper Mahaweli Catchment- a review of the published evidence. Mahaweli Authority of Sri Lanka p. 91 (1998).

17. Gunathilake, A., Senaratne, C.: Parakrama Samudra Sri Lanka Project. A study of tropical lakes ecosystem. The chemical environment with special reference to nutrient. Verh. Internat, Veren. Limnol, 21, 1000-1006. (1981).

18. Haider, S., Naithani, V., Viswanathan, P. N., Kakkar, P.: Cyanobacterial toxins: a growing environmental concern, Chemosphere, 52, 1-21 (2003).

19. Jayatissa, L. P., Lawton, L. A., Cornish, B. J. P. A.: Toxic cyanobacteria (Blue-green algae) in fresh waters of Sri Lanka, pp 32-34 In: Harmful and toxic algal blooms (T. Yasumoto, Y. Oshima, Y. Fukuyo, eds.). IOC of UNESCO. 1997. 
20. Jayatissa, L. P., Lawton, L. A., Karunatilake, R., Cornish, B. J. P. A.: Seasonal variations in the toxicity in two perennial blooms of cyanobacteria in Sri Lanka, p. 80. Compilation of abstracts, $4^{\text {th }}$ International conference of toxic cyanobacteria, North Carolina, USA. (1998).

21. Lawton, L. A., Codd, G. A.: Cyanobacterial (blue-green algal) toxins and their significance in UK and European waters. Journal of Chartered Institute of Water Environmental Management, 5, 460-465 (1991).

22. Lawton, L. A., Edwards, C., Codd, G. A.: Extraction of high-performance liquid chromatographic method for the determination of microcystins in raw and treated waters. Analyst, 119, 1525-1530 (1994).

23. McElhiney, J., Lawton, L. A., Leifert, C.: Investigations into the inhibitory effects of microcystins on plant growth, and the toxicity of plant tissues following exposure, Toxicon, 39, 1411-1420 (2001).

24. Pflugmacher, S., Wiegand, C., Beattie, K. A., Codd, G. A., Steinberg, C. E. W.: Uptake of the cyanobacterial hepatotoxin Microcystin-LR by aquatic macrophytes. Journal of Applied Botany, 72, 228-232 (1998).

25. Pflugmacher, S., Wiegand, C., Beattie, K. A.,Krause, E., Steinberg, C. E. W., Codd, G. A. Uptake, effects and metabolism of cyanobacterial toxins in the emergent reed plant Phragmites australis (Cav.) Trin. Ex Steud. Environmental Toxicology and Chemistry, 20, 846-852 (2001).

26. Pouria, S., de Andrade, A., Barbosa, J., Cavalcanti, R. L., Barreto, V.S.T., Ward, C. J., Preiser, W., Poon, G. A., Neild, G. H. Codd. G A.: Fatal microcystin intoxication in haemodialysis unit in Caruaru, Brazil, The Lancet, $352,21-26(1998)$.

27. Puiseux-Dao, S..: Phycotoxins and carcinogenesis., Toxicon, 33, 1117-11 (1995) 
28. Rott, E.: A contribution to the phytoplankton species composition of Parakrama samudra, an ancient man-made lake in Sri Lanka. In: Limnology of Parakrama Samudra - Sri Lanka - an ancient man made lake in the tropics (F. Schiemer ed). P.209-226. Developments in Hydrobiology 12, The Hauge 1983.

29. Rott, E., Lenzenweger. R.: Some rare and interesting plankton algae from Sri Lanka. Biologia, Bratislava, 49, 479-500 (1994).

30. Schiemer, F., Amarasinghe, U.S. Frouzova, J., Sricharoendhaam, B., Silva E.I.L.: Ecosystem structure and dynamics - a management basis for Asian reservoirs and Lakes pp. 111-125 In: Reservoir and Culture-Based Fisheries: Biology and Management ACAIR Proceedings, (S.S. De Silva, ed.). 98, 2001.

31. Schiemer, F., Duncan, A.: Parakrama samudra project. A summery of main results in Limnology of Parakrama Samudra. In: Limnology of Parakrama Samudra - Sri Lanka - an ancient man made lake in the topics (F. Schiemer, ed.). 201-206, Developments in Hydrobiology, 12, The Hauge 1983.

32. Schreurs, H.: Cyanobacterial dominance, relation to eutrophication and lake morphology. Thesis, University of Amsterdam (1992).

33. Silva, E.I.L: Status of surface water quality in Sri Lanka. SCOPE 82, 111-124 (1999).

34. Silva, E.I.L., Davies, R.W.: The seasonality of monsoonal primary productivity in Sri Lanka. Hydrobiologia, 150, 165 - 175 (1987).

35. Silva E.I.L., Gamlath, G.A.R.K.: Catchment characteristics and water quality of Three Reservoirs (Victoria, Minneriya and Udawalawe) in Sri Lanka. Sri Lanka Journal of Aquatic Science, 5, 55 - 73 (2000).

36. Silva E.I.L., Schiemer, F. Human Factor: Fourth Dimension of Limnology in the Tropics, In: Proceedings of International Workshop on Reservoir and 
Culture-Based Fisheries: Biology and Management (S.S. De Silva, ed.). ACAIR Proceedings, 98, 215 - 226 (2001).

37. Silva, E.I.L., Wijeyaratne, M.J.S. The occurrence of cyanobacteria in the reservoir of the Mahaweli River Basin in Sri Lanka. Sri Lanka J. Aquat Sci, 4, 51-60 (1999).

38. Smith, V. H.: Low nitrogen to phosphorus ratios favour dominance by bluegreen algae in lake phytoplankton. Science, 221, 669-671 (1983).

39. Xie, L., Xie, P., Li, S. Tang, H., Liu, H. The low TN:TP ratio, a cause or a result of Microcystis blooms? Water research, 37, 2073 -2080 (2003). 
Table 1 Water bodies sampled showing their primary use and location in relation to the main climatic zones with microcystin levels where detected. * Scum sample hence microcystin concentration determined in $\mathrm{mg}$ $\mathrm{g}^{-1}$ dry weight of cells.

\begin{tabular}{|l|l|l|l|}
\hline \multicolumn{1}{|c|}{ Water Body } & \multicolumn{1}{|c|}{ Climatic Zone } & \multicolumn{1}{c|}{ Microcystins $\left(\boldsymbol{\mu g} \mathbf{~ I}^{\mathbf{1}}\right)$} \\
\hline 1. Bandagiriya & Irrigation tank & Dry & Not tested \\
\hline 2. Chandrikawewa & Irrigation tank & Dry & None detected \\
\hline 3. Colombo Lake & Aesthetic & Lowland Wet & $0.737^{*}$ \\
\hline 4. Kalatuwawa & Drinking water & Lowland Wet & Not tested \\
\hline 5. Kandy Lake & Aesthetic & Upland Wet & $0.292^{*}$ \\
\hline 6. Kotmale & Hydropower reservoir & Upland Wet & 13.15 \\
\hline 7. Labugama & Drinking water & Lowland Wet & Not tested \\
\hline 8. Lunugamwehera & Irrigation tank & Dry & Not tested \\
\hline 9. Randenigala & Hydropower reservoir & Intermediate & 20.95 \\
\hline 10. Rantambe & Hydropower reservoir & Intermediate & Not tested \\
\hline 11. Ridiyagama & Irrigation tank & Dry & Not tested \\
\hline 12. Situlpawwa & Aesthetic & Dry & 81.31 \\
\hline 13. Tissawewa & Irrigation tank & Dry & None detected \\
\hline 14. Udawalawe & Irrigation tank & Dry & None detected \\
\hline 15. Ulhitiya & Irrigation tank & Dry & None detected \\
\hline 16. Victoria & Hydropower reservoir & Intermediate & None detected \\
\hline 17. Weerawila & Irrigation tank & Dry & Not tested \\
\hline
\end{tabular}


Table 2 Mean phytoplankton biovolumes and key water quality parameters of surface waters in 17 reservoirs

\begin{tabular}{|c|c|c|c|c|c|c|c|}
\hline \multirow[t]{2}{*}{ Reservoir } & \multicolumn{3}{|c|}{ Mean biovolume $\left(\mathrm{mm}^{3} \mathrm{l}^{-1}\right)$ of: } & \multirow[t]{2}{*}{$\mathrm{pH}$} & \multirow{2}{*}{$\begin{array}{l}\mathrm{t}-\mathrm{N} \\
\mu \mathrm{l}^{-1}\end{array}$} & \multirow{2}{*}{$\begin{array}{l}\mathrm{t}-\mathrm{P} \\
\mu \mathrm{l}^{-1}\end{array}$} & \multirow[t]{2}{*}{$\mathrm{N}: \mathrm{P}$} \\
\hline & \multicolumn{2}{|c|}{ Cyanobacteria } & \multirow{2}{*}{$\begin{array}{r}\text { Other } \\
\text { phytoplanktons } \\
77.49 \\
\end{array}$} & & & & \\
\hline 1. Bandagiriya & 8.81 & $11.36 \%$ & & $7.31 \pm 0.68$ & $47.6 \pm 18.19$ & $8.3 \pm 2.56$ & $10.2: 1$ \\
\hline 2. Chandrikawewa & 9.86 & $10.50 \%$ & 93.84 & $7.44 \pm 0.92$ & $52.7 \pm 19.36$ & $9.0 \pm 2.98$ & $5.9: 1$ \\
\hline 3. Colombo Lake & 207.3 & $96.0 \%$ & 8.7 & $8.65 \pm 0.70$ & $331.2 \pm 31.88$ & $31.0 \pm 9.00$ & $10.6: 1$ \\
\hline 4. Kalatuwawa & 1.13 & $1.46 \%$ & 77.11 & $7.16 \pm 0.42$ & $21.5 \pm 3.22$ & $7.2 \pm 1.70$ & $3.0: 1$ \\
\hline 5. Kandy Lake & 17.92 & $14.8 \%$ & 121.08 & $8.32 \pm 0.44$ & $376.4 \pm 48.87$ & $30.3 \pm 6.82$ & $12.4: 1$ \\
\hline 6. Kotmale & 6.43 & $5.0 \%$ & 127.57 & $8.21 \pm 0.61$ & $262.1 \pm 59.49$ & $27.3 \pm 8.88$ & $9.6: 1$ \\
\hline 7. Labugama & 1.85 & $2.1 \%$ & 87.25 & $6.94 \pm 0.50$ & $26.3 \pm 4.76$ & $6.1 \pm 1.45$ & $4.3: 1$ \\
\hline 8. Lunugamwehera & 9.59 & $10.3 \%$ & 83.61 & $7.46 \pm 1.22$ & $86.3 \pm 40.72$ & $14.5 \pm 7.05$ & $6.0: 1$ \\
\hline 9. Randenigala & 5.59 & $4.4 \%$ & 121.01 & $7.76 \pm 0.39$ & $182.8 \pm 39.83$ & $22.6 \pm 5.61$ & $8.0: 1$ \\
\hline 10. Rantambe & 2.65 & $3.1 \%$ & 87.75 & $7.31 \pm 0.65$ & $137.2 \pm 18.05$ & $19.4 \pm 4.67$ & $7.1: 1$ \\
\hline 11. Ridiyagama & 4.78 & $5.9 \%$ & 76.32 & $7.26 \pm 0.79$ & $66.5 \pm 17.81$ & $7.1 \pm 3.45$ & $9.4: 1$ \\
\hline 12. Situlpawwa & 21.72 & $13.1 \%$ & 144.08 & $8.31 \pm 0.48$ & $356.1 \pm 24.28$ & $26.3 \pm 7.39$ & $13.5: 1$ \\
\hline 13. Tissawewa & 17.94 & $11.7 \%$ & 135.36 & $8.26 \pm 0.62$ & $260.0 \pm 39.15$ & $31.1 \pm 8.27$ & $8.4: 1$ \\
\hline 14. Udawalawe & 8.27 & $8.6 \%$ & 87.93 & $7.75 \pm 0.59$ & $46.9 \pm 11.67$ & $12.6 \pm 3.71$ & $3.7: 1$ \\
\hline 15. Ulhitiya & 5.17 & $5.8 \%$ & 84.03 & $8.02 \pm 0.81$ & $60.0 \pm 20.33$ & $6.4 \pm 1.72$ & $9.4: 1$ \\
\hline 16. Victoria & 3.21 & $2.8 \%$ & 111.29 & $7.84 \pm 0.90$ & $238.3 \pm 43.72$ & $28.9 \pm 7.38$ & $8.2: 1$ \\
\hline 17. Weerawila & 8.28 & $11.3 \%$ & 65.02 & $7.30 \pm 1.0$ & $91.1 \pm 34.27$ & $9.2 \pm 3.87$ & $9.9: 1$ \\
\hline
\end{tabular}


Table 3 Ranks of Important value index (IVI) for the common phytoplankton species recorded in each of the 17 water bodies.

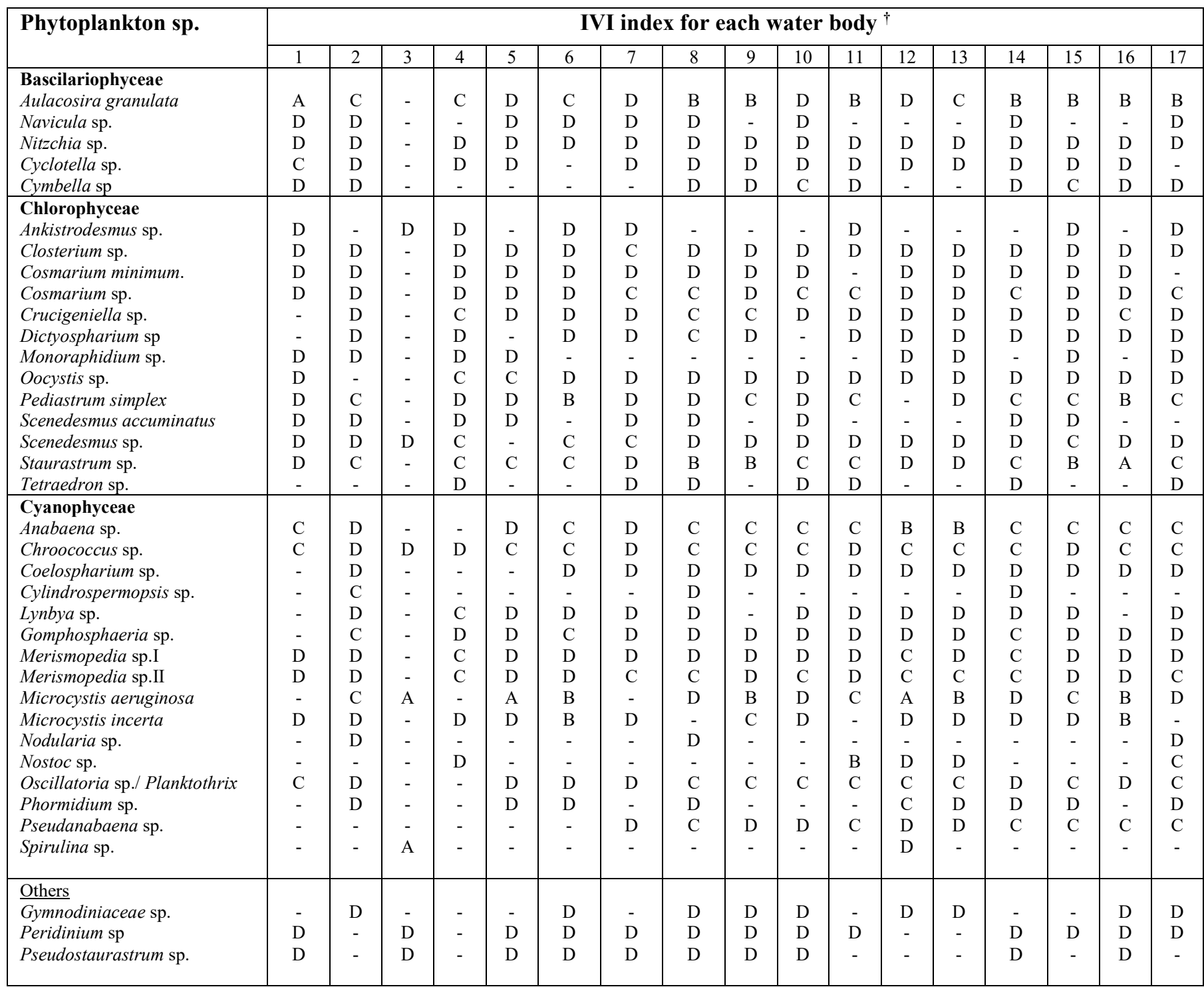

$\dagger$ IVI values were ranked as follows; $\mathrm{A}=>40, \mathrm{~B}=25-40, \mathrm{C}=10-25, \mathrm{D}=5-10$ and - indicates that the genus or species were not present in that sample. The numbers given at the top of each column correspond to each of the water bodies listed in Table 1 . 
Table 4. Microcystin level, percent biovolume of constituent cyanobacterial species (CB) and IVI for Microcystis spp. (the most common toxigenic taxa recorded in samples) in water samples withdrawn in sampling occasion in which toxins were detected

\begin{tabular}{l|l|l|l}
\hline Water body & Microcystins $(\mu \mathrm{g} 1-1)$ & \% biovolume of CB & IVI for Microcystis spp. \\
\hline Colombo Lake & $0.737^{\mathrm{a}}$ & 43.6 & 166 \\
\hline Kandy Lake & $0.292^{\mathrm{a}}$ & 15.3 & 142 \\
\hline Kotmale & 13.15 & 6.8 & 94 \\
\hline Randenigala & 20.95 & 7.3 & 72 \\
\hline Situlpawwa & 81.31 & 28.5 & 124 \\
\hline
\end{tabular}

Scum samples, hence microcystin concentration determined in mg g-1 dry weight. 